\title{
Single Marker Association with Mastitis Incidence of Three Microsatellite Loci, BM1258, BM1443 and BM1818, in Egyptian Buffalo
}

\author{
Abdullah Ghazy ${ }^{1^{*}}$, Ibrahim Atta Abu El-Naser ${ }^{2}$, Keiichiro Kizaki ${ }^{3}$ and Kazuyoshi Hashizume ${ }^{3}$ \\ ${ }^{1 *}$ Animal Production Department, Faculty of Agriculture, Suez Canal University, Ismailia 41522, Egypt \\ ${ }^{2}$ Animal Production Department, Faculty of Agriculture, Damietta University, Egypt \\ ${ }^{3}$ Department of Veterinary Medicine, Faculty of Agriculture, Iwate University, Ueda 3-18-8, Morioka 020-8550, Japan
}

Received: $10 / 2 / 2021$

\begin{abstract}
To detect the linkage between single markers of microsatellite type and mastitis incidence in Egyptian buffalo three markers (BM1258, BM1443 and BM1818) and one hundred twenty-three lactating animals were used. The selected animals were tested using Modified White Side Test (MWT) to screen animals for mastitis. Non-denatured polyacrylamide gel was used to determine the sizes of the PCR amplified products using reference animal to verify the allelic sizes obtained. For each marker, the frequencies of alleles and genotypes for both positive and negative animal groups were compared by using the chi-square test and the Fisher's exact test. The odds ratios calculated as an estimate of relative risk of mastitis incidence associated with each microsatellite genotypes. A positive mastitis test reaction (MWT) was revealed in 19.5\% of total samples. For BM1258, BM1443, and BM1818, the number of alleles was found to be 4,3 and 5, respectively. The polymorphism in all three studied loci was high (PIC $>0.5$ ). The genetic parameters of these loci, including observed and expected heterozygosity, were estimated using full characterizations of this set of three polymorphic loci. The polymorphic information content, heterozygosity, and number of successful alleles of the studied loci showed that BM1443 had the lowest variability and BM1818 had the highest variability, with 0.597 and 0.757 , respectively. The overall effects of the three studied markers on mastitis incidence were significantly $(\mathrm{P}<0.05)$ different. The genotypes combination '72/79', '74/74', and '79/82' at BM1258 loci; '78/78' and '88/88' at BM1443 loci, were observed only in the mastitis free animals. On the other hand, BM4505 loci genotypes were found in the positive populations except the combination of genotypes 134/134, 134/140 and 134/144 animals. The information observed in the present study, could be valuable for improving mastitis resistance in Egyptian buffalo breeds through using molecular tools.
\end{abstract}

Keywords: observed alleles, expected heterozygosity, Polymorphic information content, F-statistics, Hardy Weinberg equilibrium

\section{INTRODUCTION}

Buffaloes are widely distributed in different countries around the world and are of primary importance in farmers ' lives. It is the world's secondlargest producer of animal milk (Liu et al., 2018). Overall, $81 \%$ of total worldwide milk production comes from cows, while buffaloes contribute $15 \%$, and a total of $4 \%$ produced by goats, sheep and camels combined (FAO 2019). In Egypt, buffalo plays a pivotal role in overall social rural development through contributions to the dairy and meat products. Scientists generally agree that mastitis is the most common and most economically damaging infectious disease in dairy cattle (Halasa et al., 2007; Elango et al., 2010; Sharma et al., 2012; Tiwari et al., 2013). Mastitis disease is a global problem, because it adversely affects animal health, milk quality and the dairy industry, affecting all countries, and causing massive economic losses (Sharma et al., 2007). Mastitis is also spreading in parallel with the production of new, high lactating cow and buffalo breeds (Sharma et al., 2012).

Furthermore, studies in various parts of subSaharan Africa showed that in the small-scale dairy cow farms, mastitis is widespread. The prevalence of mastitis in Egyptian buffalo was $19.9 \%$ and $5.9 \%$ for clinical and subclinical mastitis respectively (El-Naker et al., 2015). Susceptibility or resistance of the host is influenced by the genetic component that regulates the efficiency of the immune response to infectious diseases. The use of molecular markers for enhance the host's genetic resistance is a critical component of

*Corresponding author e-mail: ghazy@agr.suez.edu.eg successful disease control. Better knowledge about host genetic susceptibility and/or resistance mechanisms are prerequisites for the creation of animal breeding programs that can open avenues for future successful, reliable and sustainable methods for detecting mastitis incidence in buffaloes.

Single marker analysis is one of a variety of techniques for evaluating the association between quantitative trait locus (QTL) and traits (Sharma et al., 2018). Microsatellite markers are one of many types of genetic markers that used as a useful tool in genetic studies such as population studies, determination of parentage, analysis of linkages and mapping of genomes. Therefore, the objectives of this research were to detect the linkage between single microsatellite DNA markers and mastitis incidence in Egyptian buffalo breed.

\section{MATERIALS AND METHODS}

\section{Blood collection and DNA isolation}

Totally, one hundred and twenty-three blood samples were collected from lactating Egyptian buffalo females from three different commercial farms. Once buffalos were relaxed and confident, samples were collected under aseptic conditions using vacutainer's needle and tubes. All animal handling procedures were approved by the Veterinary Medicine College Animal Ethics Committee, Suez Canal University, in compliance with the "Laboratory Animal Care and Use Guide." Blood samples $(10 \mathrm{ml})$ were collected via the jugular vein in vacuum tubes containing anticoagulant

Volume 10 (1):1 -7 
(K3EDTA). DNA was isolated from the whole blood using the ABIO pure ${ }^{\mathrm{TM}}$ Genomic DNA Kit (Alliance Bio Co.). All samples were analyzed using the Nano Drop (Spectrophotometer ND-1000) to accurately assess the quality and quantity of extracted genomic DNA. The DNA concentration was determined, and samples were diluted for obtaining a final concentration of approximate $20 \mathrm{ng} / \mu \mathrm{l}$. Animals milk samples were screened for mastitis by Modified Whiteside test (MWT) as described by (Amin et al., 2005). Animals were classified into two groups: mastitis tolerant (Negative for MWT and SCC $<250000 / \mathrm{ml}$ ) and mastitis susceptible (Positive of any grade i.e. $+/++/+++$, for MWT and SCC $>250000 / \mathrm{ml}$ ).

\section{Microsatellite analysis}

Based on earlier researches on microsatellite relationships with mastitis in cows (Hai-Guo et al., 2003; Chu et al., 2005; Gupta et al., 2016), three microsatellites (BM1258, BM1443 and BM1818) were used in this study. Primers sequences used according to cattle genome linkage map. Fitting markers annealing temperatures were identified by using grading PCR thermal cycle (Table 1).

Table (1): Sequences of bovine microsatellite marker primers, chromosome location, annealing temperatures and detected allele size range

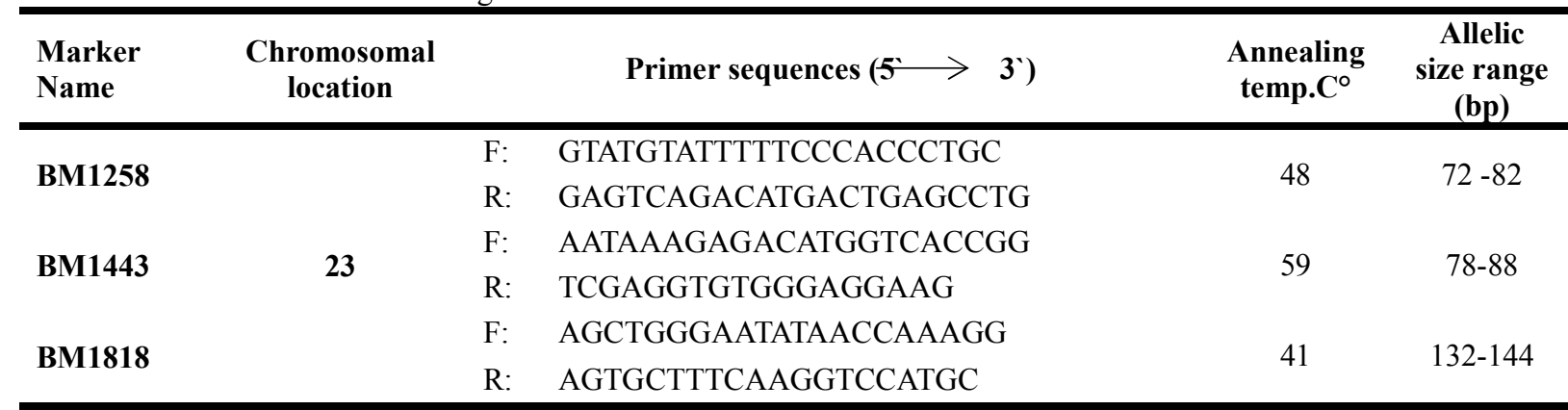

The PCR was carried out for each locus in a total volume of $10 \mu \mathrm{l}$ consisted of $2 \mu \mathrm{l}$ of Genomic DNA (20ng), $5 \mu \mathrm{l}$ 2X PCR AmpliTag gold PCR Master mix (applied biosystems), $0.4 \mu \mathrm{l}$ primer mix (50 pmoles), and $2.6 \mu \mathrm{l}$ nuclease-free $\mathrm{H}_{2} \mathrm{O}$. The PCR protocol was displayed in Table (2). The PCR protocol was the same for all primers except for annealing temperature that was varied as previously described (Table 1).

Table (2): The optimized conditions of PCR for selected three microsatellites loci

\begin{tabular}{lcc}
\hline Steps & Temperature & Time \\
\hline Initial denaturation & $95^{\circ} \mathrm{C}$ & $10 \mathrm{~min}$. \\
Denaturation & $95^{\circ} \mathrm{C}$ & $30 \mathrm{sec}$. \\
Annealing & $\mathrm{As}$ determined & $30 \mathrm{sec}$. \\
Extension & $72^{\circ} \mathrm{C}$ & $30 \mathrm{sec}$. \\
\hline Steps 2 to 4 were to be repeated for 35 cycles \\
\hline Final extension & $72^{\circ} \mathrm{C}$ & $10 \mathrm{~min}$. \\
Maintenance & $4^{\circ} \mathrm{C}$ & $\infty$ \\
\hline
\end{tabular}

An equal amount $(3 \mu \mathrm{l})$ of each reaction product was added to $1 \mu \mathrm{l}$ of $6 \mathrm{X}$ loading dye and run on vertical $8 \%$ polyacrylamide gel (Plates 1 to 3 ). Molecular weight of each band in a gel (bp) was identified by comparison with the 50 bp DNA ladder, a reference animal was used to adjust allelic sizes in separated gels.

\section{Statistical analysis}

Bio-Rad Quantity One Software Package (version 4.6.3) was used to analyze electrophoresis gels. Based on allele size data, genotypes were appointed to each animal. The number of alleles $(\mathrm{N})$, allele frequency, observed heterozygosity $\left(\mathrm{H}_{\mathrm{ob}}\right)$ and expected heterozygosity $\left(\mathrm{H}_{\mathrm{exp}}\right)$ per locus were calculated using FSTAT software (version 2.9.3.2) (Goudet, 2002; Nei, 1987). Wright's F-statistic inbreeding coefficient $\left(F_{I S}\right)$ were computed by using GENEPOP software (version 3.4) (Nei and Kumar, 2000). Also, Hardy-Weinberg equilibrium (HWE) was tested over loci using previous software. According to Botstein (Botstein et al., 1980) the polymorphic information content (PIC) values were calculated.

The univariate logistic regression analysis considered the status of the infection as categorical response variable (0/1). The PROC LOGISTIC procedure of SAS 9.3 was used to find out the overall association of the microsatellite loci with mastitis. Furthermore, individual allelic frequencies within each microsatellite markers were compared using PROC FREQ procedure of SAS and the ODDs ratio (ORs) of genotypes were calculated in affected population (Positive='1'; Negative='0') for calculating the relative risk. The Fisher's exact and chisq probabilities were calculated in case the frequencies in a cell were less than $5 \%$. Odds Ratio (OR) was determined for each genotype frequency with $95 \%$ confidence intervals.

\section{RESULTS AND DISCUSSION}

Microsatellites polymorphism and heterozygosity

Number of alleles, heterozygosity, polymorphism information content (PIC), Wright's F-statistics $\left(\mathrm{F}_{\mathrm{IS}}\right)$ value, and Chi-square test and $\mathrm{P}$ value of Hardy Weinberg equilibrium (HWE) are presented in Table (3), all studied microsatellite loci were polymorphic. 
Table (3): Number of observed alleles $\left(\mathrm{N}_{\mathrm{a}}\right)$, observed $\left(\mathrm{H}_{\mathrm{ob}}\right)$ and expected heterozygosity $\left(\mathrm{H}_{\text {exp }}\right)$, Polymorphic information content (PIC), Wright's F-statistics $\left(\mathrm{F}_{\mathrm{IS}}\right)$ value and Chi-square test and $\mathrm{P}$ value of Hardy Weinberg equilibrium (HWE) at three different microsatellite loci

\begin{tabular}{lccccccc}
\hline \multirow{2}{*}{ Loci } & $\mathbf{N}_{\mathbf{a}}$ & $\mathbf{H}_{\text {exp }}$ & $\mathbf{H}_{\mathbf{o b}}$ & $\mathbf{P I C}$ & $\mathbf{F}_{\text {IS }}$ & \multicolumn{2}{c}{ HWE } \\
\cline { 5 - 8 } BM1258 & 4 & 0.6676 & 0.9024 & 0.5938 & -0.37 & 29.1 & 0.000058 \\
BM1443 & 3 & 0.5977 & 0.8049 & 0.5122 & -0.36 & 21.2 & 0.000095 \\
BM1818 & 5 & 0.7573 & 0.9268 & 0.7029 & -0.24 & 53.8 & 0.000000 \\
Mean & 4 & 0.6742 & 0.8780 & 0.6 & -0.3184 & & \\
SD & & 0.08 & 0.0645 & & & &
\end{tabular}

The mean number of alleles is a better predictor of the genetic polymorphism within the population (Hassen et al., 2012). It also depends on sample size of the population due to the possible existence of unique alleles that may appear at low frequencies (Qwabe, 2012). A high number of alleles imply more genetic variation (Nei, 1987). In the present study, four alleles at the BM1258 microsatellite DNA loci were detected in the Egyptian buffalo population. The variants ranged from 72 to $82 \mathrm{bp}$ (Plate 1).
Three alleles were detected at the BM1443 microsatellite DNA loci and their size were ranged from 78 to $88 \mathrm{bp}$ (Plate 2). While, five alleles were found at the BM1818 loci and their size were varied between 132 and $144 \mathrm{bp}$ (Plate 3).

In total, 12 alleles were detected in the three microsatellite DNA loci when they were screened in the 123 lactating Egyptian buffalo females. Hai-Guo et al. (2003) detected 4, 5 and 8 alleles in BM1818, BM1258 and BM1443 loci, respectively, in 240 Beijing Holstein cows.

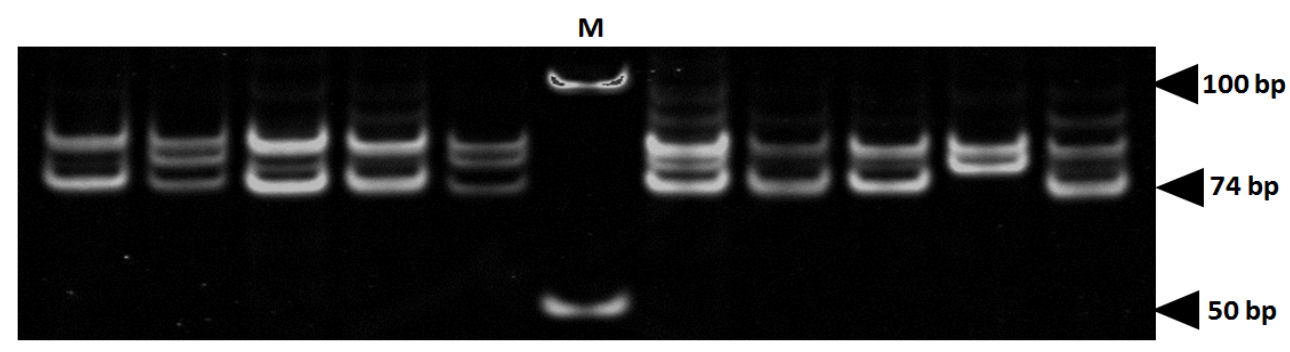

Plate 1. Polyacrylamide gel (8\%) showing alleles concerning BM1258 marker. DNA ladder is in well M

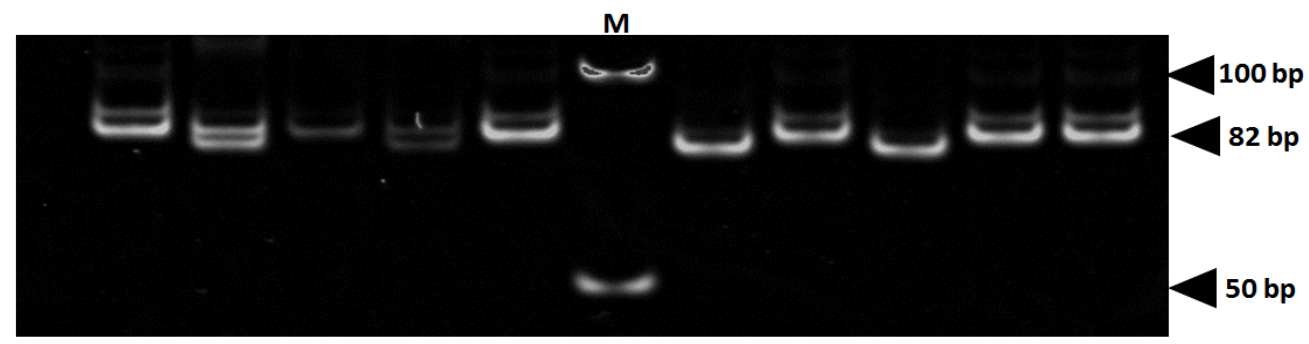

Plate 2. Polyacrylamide gel (8\%) showing alleles concerning BM1443 marker. DNA ladder is in well M

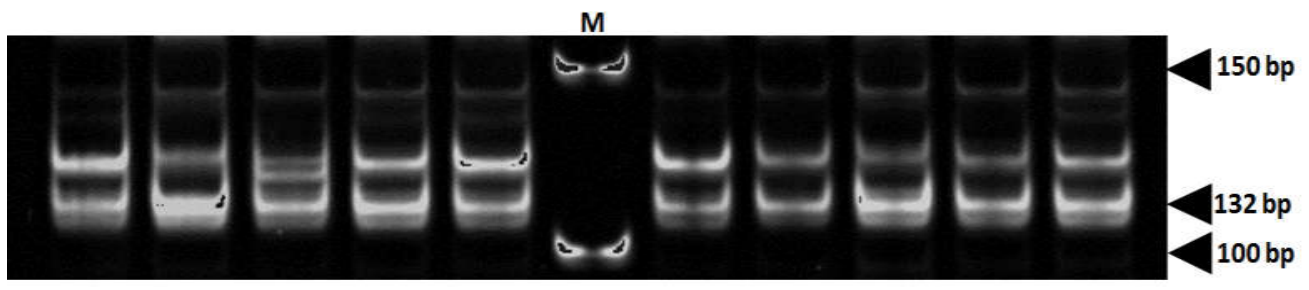

Plate 3. Polyacrylamide gel (8\%) showing alleles concerning BM1818 marker. DNA ladder is in well M 
Rushdi et al. (2017) reported a poor amplification of BM1258 with Egyptian buffalo. While, Ángel-Marín et al. (2010) observed 14 alleles for BM1258 with Colombian buffalo breed. Joshi et al. (2015) found that BM1443 locus has 15 alleles with Indian buffalo. Sukla et al. (2006) found BM1818 had 7 alleles in Indian buffalo. Toro et al. (2009) reported that the most widely used parameters to measure genetic diversity in a population are the observed heterozygosity, expected heterozygosity and following the Hardy-Weinberg proportions. Literature suggested that levels of heterozygosity above 0.5 values were considered appropriate for genetic diversity studies (Dávila et al., 2009). The highest heterozygosity (Table 2) was found at locus BM1818 (0.7573) followed by BM1258 (0.6676). Meanwhile, the lowest heterozygosity was found at loci BM1443 (0.5977). An average heterozygosity per locus was estimated at 0.6742 . The heterozygosity (both observed and expected) estimates in the Egyptian buffalo population were relatively high, indicating that the studied buffalo population had high amount of within population genetic diversity. The $\mathrm{H}_{\mathrm{ob}}$ and $\mathrm{H}_{\text {exp }}$ mean values for the three studied loci were higher than those recorded in different buffalo breeds (Kataria et al., 2009; Kathiravan et al., 2009), but this is similar with results that observed in Indian buffaloes population by (Mishra et al., 2009), and in European buffalo populations by (Moioli et al., 2001). In our study, within-population heterozygote deficiency or inbreeding $\left(\mathrm{F}_{\mathrm{IS}}\right)$ was estimated (Table 3). Estimates of inbreeding coefficient or $F_{I S}$ values of three microsatellites were negative and between -0.24 at BM1818 and -0.37 at BM1258 with mean -0.3184 . The $\mathrm{F}_{\mathrm{IS}}$ moderate negative values may be resulted from outbreeding levels of selected unrelated animals in different studied farms or may be the controlled and planned mating program that was used in these farms depicting low levels of inbreeding (Dorji et al., 2012). Also, inbreeding coefficient $\left(\mathrm{F}_{\mathrm{IS}}\right)$ values showed a significant deviation from the Hardy-Weinberg equilibrium (HWE). The Polymorphic information content (PIC) showed the suitability of the markers and their primers used in the analysis to evaluate a population's genetic variability. According to Botstein et al. (1980) a marker is highly informative if its PIC is greater than 0.5 . In the present study, all the three markers were informative. The highest PIC value was obtained for the microsatellite marker BM1818 (0.7029), followed by BM1258 (0.5938) and BM1443 (0.5122). Similar to this study, Greyling et al. (2008) found high PIC values in an African buffalo population, thereby demonstrating that the microsatellites examined in this study were useful for the genetic characterization of buffalo populations.

\section{Effect of genotypes at microsatellite loci on mastitis incidence}

Comparison of individual 18 genotypes of these three microsatellite markers were observed in Table (4). Individual genotypic frequencies at both BM1258 and BM1443 microsatellite loci represented five genotypes.
Whilst, BM1818 locus represented eight genotypes. The overall effects of the three studied markers on mastitis incidence were significantly $(\mathrm{P}<0.05)$ different. BM1258 genotypes 79/72bp, 74/74 bp, and 79/82 bp were observed only in the mastitis free samples. Similarly, BM1443 genotype locus $78 / 78$ bp and $88 / 88$ bp represented only in negative samples. In case of BM4505 microsatellite, all genotypes didn't exist in positive population except thee genotype 134/134, $134 / 140$ and 134/144 which were presented exclusively in mastitis negative animals, while genotype 134/134 and 134/140 were present exclusively only in mastitis positive animals. Odds ratios were calculated as an estimate of relative risk of mastitis incidence associated with each microsatellite genotypes.

There was no risk associated with $132 / 132 \mathrm{bp}$, $132 / 140$ bp, 132/142 bp, 132/144 bp and 134/142 bp genotypes of BM1818 loci. While, there was excess risk associated with three genotypes $134 / 134 \mathrm{bp}$, so it could be a potential candidate marker to identify animals susceptible for mastitis. Chu et al. (2005) studied the genetic variation of seven microsatellite loci in Beijing Holstein cows which were closely linked to Somatic Cell Score (SCS) and found a significant association with the SCS. Also, Gupta et al. (2016) analyzed the association between five microsatellite loci and SCS in 76 Indian crossbred cows. They reported that BM1818 marker not associated with SCS in studied population. Based on association with Somatic Cell Count (SCC), Ranjan et al. (2017) detected significant marker allele affecting the incidence of mastitis for markers in crossbred cattle.

\section{CONCLUSION}

This study has gone some way towards enhancing our understanding of genetic characteristics of three microsatellite DNA loci and their association with mastitis incidence in Egyptian buffalo. This research has highlighted three polymorphic loci that might be relied upon as a useful tool to reduce the incidence of mastitis in buffalo herds by incorporating them in the selection program. The consequences of this study showed some microsatellite genotypes which may act as marker for susceptibility/resistance to mastitis incidence. Extension of research on associated gene polymorphism to a large population and exploration of the association of different molecular markers on these genes may complement traditional selection methods.

\section{Conflict of interest}

We certify that there is no conflict of interest with any financial organization regarding the material discussed in the manuscript.

\section{ACKNOWLEDGEMENT}

I would like to acknowledge all staff members of Laboratory of Physiology, Veterinary Department, Faculty of Agriculture, Iwate University, Japan for their academic and technical supports of this research. 
Table (4): Genotypes differing significantly in positive-negative animals

\begin{tabular}{|c|c|c|c|c|c|c|}
\hline \multirow{2}{*}{$\begin{array}{c}\text { Microsatellite } \\
\text { and their alleles }\end{array}$} & \multicolumn{2}{|c|}{ Mastitis positive } & \multicolumn{2}{|c|}{ Mastitis negative } & \multirow{2}{*}{$\chi^{2}$} & \multirow{2}{*}{$\begin{array}{l}\text { Odds ratio } \\
\text { (95\% CI) }\end{array}$} \\
\hline & $\mathbf{N}$ & Frequency & $\mathbf{n}$ & Frequency & & \\
\hline \multicolumn{7}{|l|}{ BM1258 } \\
\hline $72 / 79$ & 0 & 0 & 3 & 2.4 & 0.0000 & 1.000 \\
\hline $72 / 82$ & 6 & 4.9 & 39 & 31.7 & 0.0046 & $>999.999$ \\
\hline $74 / 74$ & 0 & 0 & 12 & 9.8 & 0.0000 & 1.000 \\
\hline $74 / 82$ & 18 & 14.6 & 39 & 31.7 & 0.0056 & $>999.999$ \\
\hline $79 / 82$ & 0 & 0 & 6 & 4.9 & 0.0000 & 1.000 \\
\hline \multicolumn{7}{|l|}{ BM1443 } \\
\hline $78 / 78$ & 0 & 0 & 6 & 4.9 & 0.0000 & 1.000 \\
\hline $72 / 82$ & 6 & 4.9 & 15 & 12.2 & 0.0027 & $>999.999$ \\
\hline $82 / 82$ & 3 & 2.4 & 12 & 3 & 0.0025 & $>999.999$ \\
\hline $82 / 88$ & 15 & 12.2 & 63 & 51.2 & 0.0025 & $>999.999$ \\
\hline $88 / 88$ & 0 & 0 & 3 & 2.4 & 0.0000 & 1.000 \\
\hline \multicolumn{7}{|l|}{ BM1818 } \\
\hline $132 / 132$ & 0 & 0 & 6 & 4.9 & 0.0025 & $<0.001$ \\
\hline $132 / 140$ & 0 & 0 & 3 & 2.4 & 0.0013 & $<0.001$ \\
\hline $132 / 142$ & 0 & 0 & 33 & 26.8 & 0.0139 & $<0.001$ \\
\hline $132 / 144$ & 0 & 0 & 21 & 17.1 & 0.0089 & $<0.001$ \\
\hline $134 / 134$ & 3 & 2.4 & 0 & 0 & 0.0007 & $>999.999$ \\
\hline $134 / 140$ & 3 & 2.4 & 0 & 0 & 0.0007 & $>999.999$ \\
\hline $134 / 142$ & 0 & 0 & 3 & 2.4 & 0.0013 & $<0.001$ \\
\hline $134 / 144$ & 18 & 14.6 & 33 & 26.8 & 0.0056 & $>999.999$ \\
\hline
\end{tabular}

\section{REFERENCES}

Amin, A. A., S. A. Mokhtar and A. Ghazy (2005). Genetic analysis of the relationship among Test-day milk yield, somatic cell count and some udder characteristics of Holstein Friesian cows. Egyptian Journal of Animal Production, 42(2): 71-85.

Ángel-Marín, P. A., H. Cardona, M. Moreno-Ochoa and M. F. Cerón-Muñoz (2010). Analysis of genetic diversity in Colombian buffalo herds. Revista Colombiana de Ciencias Pecuarias, 23(4): 411-21.

Botstein, D., R. L. White, M. Skolnick and R. W. Davis (1980). Construction of a genetic linkage map in man using restriction fragment length polymorphisms. Am. journal of human genetics, 32(3): 314.

Chu, M. X., G. L. Zhou, H. G. Jin, W. H. Shi, F. C. Cao, L. Fang, S. C. Ye and Y. Zhu (2005). Study on relationships between seven microsatellite loci and somatic cell score in Beijing Holstein cows, 32(5): 471-5.

Dávila, S. G., M. G. Gil, P. Resino-Talaván and J. L. Campo (2009). Evaluation of diversity between different Spanish chicken breeds, a tester line, and a White Leghorn population based on microsatellite markers. Poultry Science, 88(12): 2518-2525.

Dorji, N., M. Duangjinda and Y. Phasuk (2012). Genetic characterization of Bhutanese native chickens based on an analysis of Red Junglefowl (Gallus gallus gallus and Gallus gallus spadecieus), domestic Southeast Asian and commercial chicken lines (Gallus gallus domesticus). Genetics and molecular biology, 35(3): 603-609.

El-Naker, Y., M. Sayed-Ahmed, Z. Saad, E. Reiad and E. Younis (2015). Prevalence of buffalo mastitis in dakahlia governorate. Assiut Vet Med J., 61(147): 56-65.

Elango, A., K. A. Doraisamy, G. Rajarajan and G. Kumaresan (2010). Bacteriology of sub clinical mastitis and antibiogram of isolates recovered from cross bred cows. Indian Journal of Animal Research, 44(4): 280-4.

FAO (2019) 'Dairy and dairy products: OECD-FAO agricultural outlook 2019-2028 C OECD/FAO2019.'Available at http://www.fao.org/3/CA4076EN/CA4076EN_ Chapter7_Dairy.pdf [Verified 31 July 2017] 
Goudet, J. (2002). FSTAT, a program to estimate and test gene diversities and fixation indices. http://www2 unil ch/popgen/softwares/fstat htm.

Greyling, B. J., P. Kryger, S. Du Plessis, W. F. Van Hooft, P. Van Helden, W. M. Getz and A. D. Bastos (2008). Development of a highthroughput microsatellite typing approach for forensic and population genetic analysis of wild and domestic African Bovini. African journal of biotechnology, 7(5).

Gupta, J. P., B. Bhushan, M. Panigrahi, S. Ranjan, V. N. Asaf, A. Kumar, S. Sulabh, A. Kumar, P. Kumar and D. Sharma (2016). Study on genetic variation of short tandem repeats (STR) markers and their association with somatic cell scores (SCS) in crossbred cows. Indian Journal of Animal Research, 50(4): 450-4.

Hai-Guo, J., Z. Guo-li, C. Yang and C. Ming-Xing (2003). Study on genetic variation of 4 microsatellite DNA markers and their relationship with somatic cell counts in cow milk. journal of animal sciences, 16(10): 15359.

Halasa, T., K. Huijps, O. Østerås and H. Hogeveen, (2007). Economic effects of bovine mastitis and mastitis management: A review. Veterinary quarterly, 29(1): 18-31.

Hassen, H., S. Lababidi, B. Rischkowsky, M. Baum and M. Tibbo (2012). Molecular characterization of Ethiopian indigenous goat populations. Tropical Animal Health and Production, 44(6): 1239-46.

Joshi, J., R. K. Salar, P. Banerjee, U. Sharma and M. S. Tantia (2015). Assessment of Genetic Variability and Structuring of Riverine Buffalo Population (Bubalus bubalis) of Indo-Gangetic Basin. Animal Biotechnology, 26(2): 148-55.

Kataria, R. S., S. Sunder, G. Malik, M. Mukesh, P. Kathiravan and B. P. Mishra (2009). Genetic diversity and bottleneck analysis of Nagpuri buffalo breed of India based on microsatellite data. journal of genetics, 45(7): 826.

Kathiravan, P., B. P. Mishra, R. S. Kataria and D. K. Sadana (2009). Evaluation of genetic architecture and mutation drift equilibrium of Marathwada buffalo population in Central India. Livestock Science, 121(2-3): 288-93.

Liu, J. J., A. X. Liang, G. Campanile, G. Plastow, C. Zhang, Z. Wang, A. Salzano, B. Gasparrini, M. Cassandro and L. G. Yang (2018). Genomewide association studies to identify quantitative trait loci affecting milk production traits in water buffalo. Journal of dairy science, 101(1): 433-44.

Mishra, B. P., R. S. Kataria, P. Kathiravan and D. K. Sadana (2009). Microsatellite based genetic characterization of Jaffarabadi buffaloes.
Indian Veterinary Journal, 86(4): 376-9.

Moioli, B., A. Georgoudis, F. Napolitano, G. Catillo, E. Giubilei, C. Ligda and M. Hassanane (2001). Genetic diversity between Italian, Greek and Egyptian buffalo populations. Livestock Production Science, 70(3): 203-11.

Nei, M. (1987). Molecular evolutionary genetics. Columbia university press.

Nei, M. and S. Kumar (2000). Molecular evolution and phylogenetics. Oxford university press.

Qwabe, S. O. (2012). Genetic and phenotypic characterisation of the South African Namaqua Afrikaner sheep breed. [Tese Genetic and phenotypic characterisation of the South African Namaqua Afrikaner sheep breed]. University of Pretoria.

Ranjan, S., B. Bhushan, J. P. Gupta, V. N. M. Asaf, M. Panigrahi, A. Kumar and R. Raveendran (2017). Study on Genetic Variation of Microsatellite and Their Association with Mastitis Occurrence in Crossbred Cattle. Journal of Animal Research, 7(1): 127-32.

Rushdi, H. E., R. E. A. Moghaieb, H. Abdel-Shafy and M. A. M. Ibrahim (2017). Association between microsatellite markers and milk production traits in Egyptian buffaloes. Czech Journal of Animal Science, 62(9): 384-91.

Sharma, N., S. K. Maiti and K. K. Sharma (2007). Prevalence, etiology and antibiogram of microorganisms associated with Sub-clinical mastitis in buffaloes in Durg, Chhattisgarh State (India). International Journal of Dairy Science, 2(2): 145-51.

Sharma, N., G. J. Rho, Y. H. Hong, T. Y. Kang, H. K. Lee, T. Y. Hur and D. K. Jeong (2012). Bovine mastitis: an Asian perspective. Asian Journal of Animal and Veterinary Advances, 7: 45476.

Sharma, U., P. Banerjee, J. Joshi, P. Kapoor and R. K. Vijh (2018). Identification of quantitative trait loci for fat percentage in buffaloes. Indian Journal of Animal Science, 88(1): 714-723.

Sukla, S, B. R. Yadav and T. K. Bhattacharya (2006). Characterization of Indian riverine buffaloes by microsatellite markers. Asian-australasian journal of animal sciences, 19(11): 1556-60.

Tiwari, J. G., C. Babra, H. Tiwari, V. Williams, S. De Wet, J. Gibson, A. Paxman, E. Morgan, P. Costantino, R. Sunagar and S. Isloor (2013). Trends in therapeutic and prevention strategies for management of bovine mastitis: an overview. Journal of Vaccines \& Vaccination. 4(1): 1-11.

Toro, M. A., J. Fernández and A. Caballero (2009). Molecular characterization of breeds and its use in conservation. Livestock Science, 120(3): 174-95. 


\section{تحليل الارتباط بين العلامات الوراثية المفردة والإصابة بالتهاب الضرع لثلاثة مواقع من نوع الميكروستاليت BM1818 BM1443 BM1258}

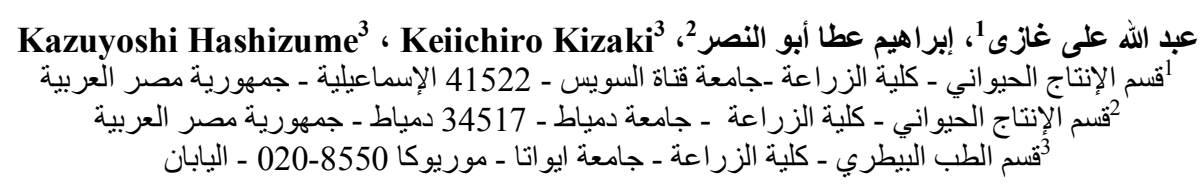

للكثف عن الارتباط بين العلامات الور اثثة المفردة من نوع الميكروستاليت والإصابة بالتهاب الضر ع في الجاموس المصري تم استخدام

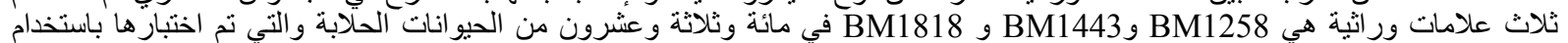

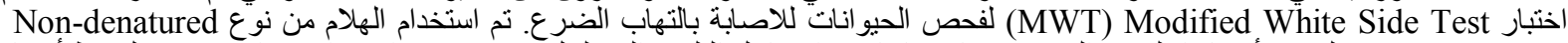

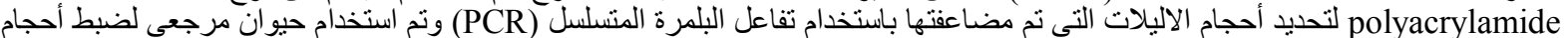

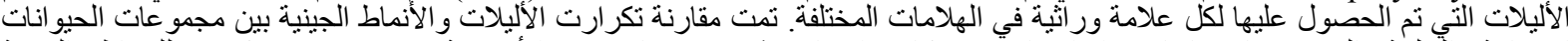

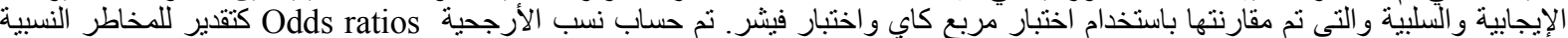

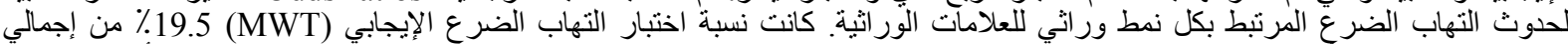

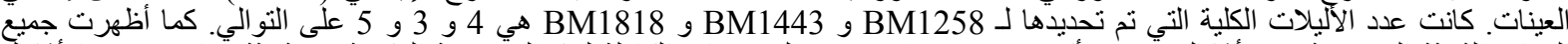

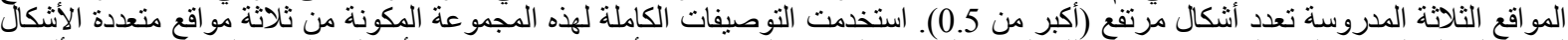

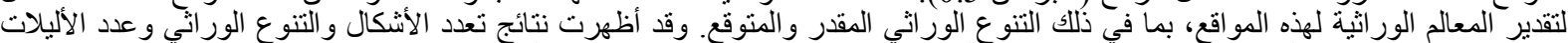

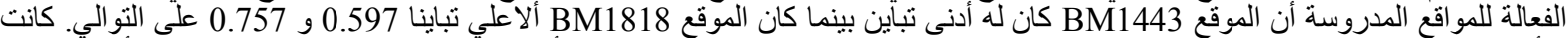

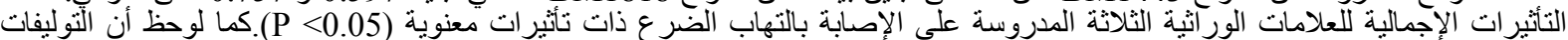

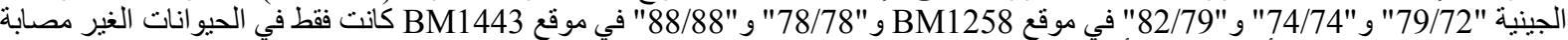

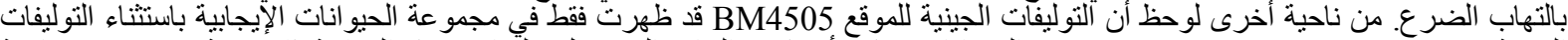

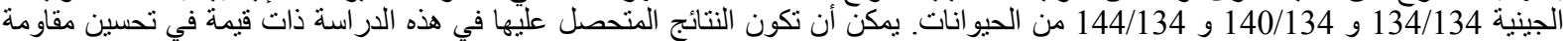

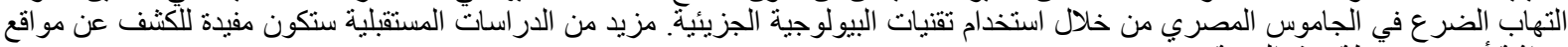

